\section{STUDENTS' CRITICAL THINKING AS AN ASPECT OF INFORMATIONAL AND PSYCHOLOGICAL SAFETY OF A PERSON}

A common issue of informational and psychological security is the subject to many studies as a foreign, Russian and national psychology. These studies acquired particular relevance both in theory and in application terms at the present stage when fundamental changes in society and the world occur. This is due to several following factors as rapid development of computer technology, a global increase in information flows and increase in threat of exposure to the conscious and unconscious parts of individual psyche against the background of the low level of information culture among population (G. Grachev, I.K. Melnik, V. Ilyukhin, B .N. Lopatin, G.V. Emelyanov et al).

Information-psychological security of the person - it is protection of the vital interests of the individual in the field of information and awareness of the personality of negative information and psychological impacts and the development of mechanisms to counter. The question of information and individual psychological security criteria is very complex, multifaceted and ambiguous because of the duality in its concept subjectivity. What appears to be some threat information to one person may not correspond to other views the same.

The purpose of this research is to study students' critical thinking as an important component of informational and personal psychological safety.

The object of this research is to realize what informational and personal psychological safety is.

The research organization and process description. The empirical work is carried out on the basis of the Almaty branch of Saint Petersburg Trade Unions University among students of the 2nd and 4th years majoring in «Psychology» and «Economy»

The subject of research is students' critical thinking.

Critical thinking is reasonable reflective thinking focused on deciding what to believe or what to do which was defined by Judy A. Brouse, David Wood.

In the philosophy of the twentieth century critical thinking has been viewed from the standpoint of consciousness, self-knowledge and morality. I.H. Sechenov proves in his writings that it is selfdetermination that enables the criticality of consciousness, allowing to separate the inside from the outside, analyze and compare. 
A. Binet was the first researcher who conducted a pilot study to determine the children's ability of being criticality. B. Shtern and Piaget explored critical thinking in general psychological terms and argued that it provides a higher degree of understanding in the learning process [1]. D. Dewey introduced the term "critical rationalism" which means the high awareness of person's own activities, opportunities and implications [2]. The scientific work of these scientists contributed to the allocation of critical thinking as a separate issue.

Further, the issue of critical thinking has been studied mainly in the framework of thinking theory. In understanding by B.V. Zeigarnik critical thinking is a regulatory function that determines the ability to check and correct people's own actions, that is, deliberately to act in accordance with objective reality. [3] S.I. Wexler examines the criticality assessment as a process of problem solving and results of personal actions. The rating determines the truth of the facts under discussion, error detection or value of objects or phenomena of reality [4]. According to N.A. Mechinskoy one of the main means of critical thinking is a reflection [5]. Many authors (EA Ivanov, SI Veksler, GIBezenkov) define critical thinking as a property of the individual and interconnect it with the attitudes, beliefs, temperament, emotional and volitional.

In the second half of the twentieth century in the leading countries of Europe a special line of pedagogy which is media education was developed and it still remains relevant today. This area is designed to help the younger generation to adapt and learn how to operate successfully in the information environment. The main approach to media education is the development of critical thinking. A.V.Fedorov formulated the modern understanding of critical thinking in relation to functioning of information system in society. Critical thinking is a complex reflexive process which includes perception, synthesis, analysis and evaluation mechanisms of the information society, which is a criterion of information competence and includes the ability to interpret and critically analyze the available information [6].

Thus, critical thinking is the kind of thinking that helps to be critical of any claims without taking anything for granted without a proof, but at the same time be open to new ideas, methods. Critical thinking is a freedom of choice, the quality of the forecast, the responsibility for own decisions.

The theoretical basis of the theory of media education is a synthesis of "protection", "ideological" and "semiotic" theories. In our study, the most important are the "protective" theory developed by L. Masterman, L. Simeli, A.V.Fedorov et al. Their main aim is the protection against the negative impact of information.

Critical thinking in this context serves as a social and independent thinking. The most important mental skills that are reflected in the most modern concepts of critical thinking skills are such as assessment of information sourcesreliability; the ability to identify relevant information and the ability to further its processing; analysis and evaluation of statements, assumptions, conclusions, arguments and hypotheses, beliefs; the ability to ask questions in order to obtain more accurate information and its verification; examination of this issue from different angles and comparing different positions and approaches; clarity of his own position, accuracy in the choice of language means; decision-making and the ability to justify his choice. That critical thinking serves as the primary means of protection against the negative information and its psychological impact.

Research by D.S.Sinitsynis dedicated to the protection from negative information and psychological impacts and finding ways to ensure that the informational and psychological safety as a whole. It offers an introduction to the "informational and psychological security" as a primary course to combine the teachers' efforts. The author considers it necessary to have knowledge about the threats and dangers of information space, to be able to allocate, process and analyze information and on this basis to make decisions. A prerequisite informational and psychological security is to install on the criticality of all information flows and critical thinking as a whole [7].

Thus, critical thinking is one of the most important ways of protections of individual conditions fromnegative information impact that determines its choice as a criterion of informational and psychological security.

In order to determine the level of critical thinking, a critical thinking test by method of A. Starkey in the adaptation of E.L.Lutsenkois used [8]. Methods of determining the critical thinking level by an American author L. Starkey is an objective test of ability and has been adapted by E.L.Lutsenko in 2014, meets the requirements of psychometric reliability, discriminative, validity and equipped with standards for student and adult age groups of both sexes.

The technique is designed for the age group from 16 to 70 years, it consists of 27 questions and statements and the correct answers. The processing 
done with key answers calculated overall critical thinking which may be between $0-27$ points. The resulting figure corresponds to low, medium or high level of critical thinking. Intragroup results of the distribution by levels of critical thinking are presented in Figure 1.

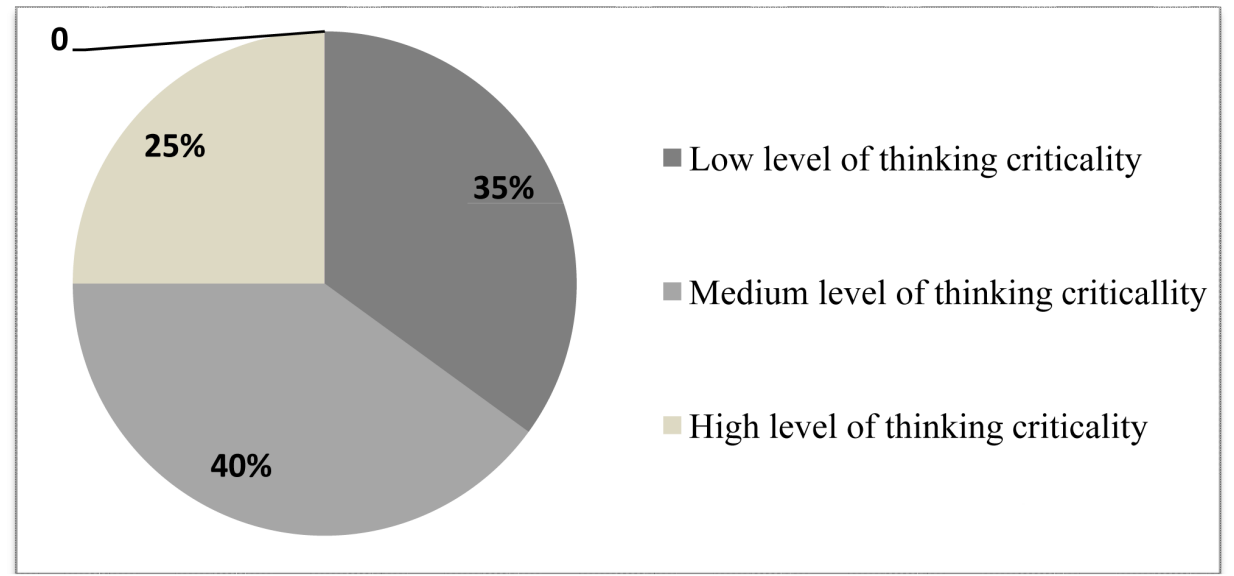

Figure 1 - The distribution by levels of critical thinking

Thus, $35 \%$ of respondents have low levels of critical thinking and logic are characterized by underdevelopment, not able to determine the objectivity of information, to identify manipulation, make informed decisions, respectively facts. Such students are exposed to the negative impact of information, the influence of cults and authoritarian ideologies. They do not trust science and resist the knowledge dissemination through addiction to alcohol, gambling, television or other types of addictions. They follow ancient traditions and instincts and little use of adaptive possibilities of mind. Such people are often not aware of their mistakes and fall victim to manipulation "pawns in the game." And only $25 \%$ of respondents have a high level of critical thinkingdevelopment, logic, induction, deduction, reflection. This group of students is the ability to identify the cause and effect relationship, highlight the facts of estimates and assumptions that generate the optimum, sophisticated and responsible decisions in conditions of uncertainty and risk are able to set realistic goals and find appropriate ways to achieve them have the advantage of adapting to changing environmental conditions.

The results of the samples tested analysis by the data presented in Figure 2.

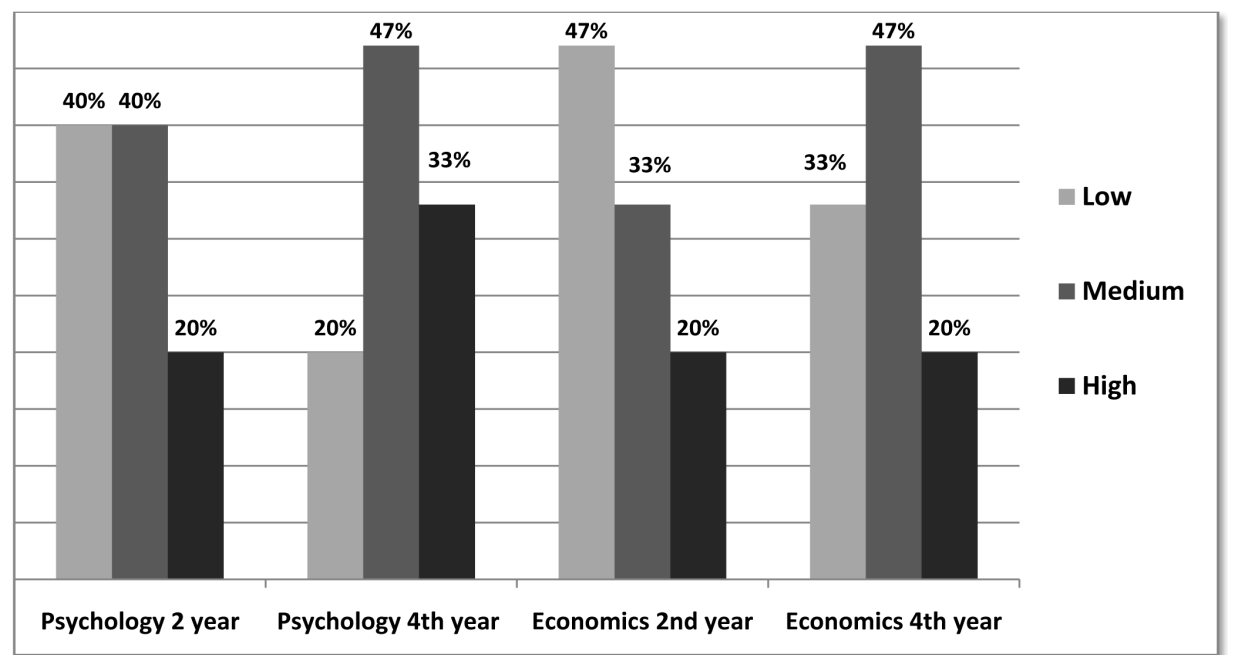

Figure 2 $-2^{\text {nd }}$ and $4^{\text {th }}$ yearstudents'criticalthinkingabilitiesmajoringinPsychology and Economics departments 
The diagram shows that a low level of critical thinking is more revealed in a group of students majoring in Economics. There is a tendency of a decrease in the share of this indicator among allstudents of 4 year in both departments.

The average level of thinking criticality largely identified in a group of psychology students. There is a tendency to increase the indicator proportion among $4^{\text {th }}$ year students in the department of Psychology.

The high level of critical thinking is largely revealed in a group of $4^{\text {th }}$ year psychology students than the economics students. There is a tendency of a decrease in the share of this indicator among $4^{\text {th }}$ year psychology students. Perhaps this is due to the fact that the current professional training, as a rule, does not address the issues of specialized training in the field of informational and personal psychological security.

Thus, psychology students' critical thinking indicators tend to show an increase and improvement during their education period. This is probably possible due to the specifics of their course which is the same for students of economists department. The results obtained and findings made can be applied to optimize the process of professional education of future specialists in higher education system and improve the level of informational and psychological safety of the person as a whole.

In fact, providing informational and psychological safety is a difficult task and requires a lot of effort and coordination of numerous organizations interactions and self-activity of each person individually.

The Kruskal - Wallis G criteriain SPSS 20 softwareisusedfor comparison of different departments' students' critical thinking ability.

It is established that between samples of 2 nd year students $(p=0.038)$ and $4^{\text {th }}$ year students $(0,013)$ of "Psychology" and "Economy" departments, there are non-random differences in critical thinkinglevels. There is a non-random shift in the direction of critical thinking indicators increase among psychology students $(p=0.002)$ of 2 nd and 4th years.

Thus, Psychology students show an increase in the critical thinking indicators. It is probably possible due to the specific of acquired specialty because a similar change is not revealed among students of Economics Department. The results obtained and made based on these findings can be applied to optimize the process of professional studies of future specialists in higher system and improve the level of informational and personal psychological safety as a whole.

\section{References}

1 Shtern V. Monografija o dushevnom razvitii rebenka. - SPb., 1911. - $147 \mathrm{~s}$.

2 D'jui D. Psihologija i pedagogika myshlenija: perevod s angl. - M.: Labirint, 2009. - 189 s.

3 3ejgarnik B.V. Patopsihologija. - M.: Smysl, 2007. - 367 s.

4 Veksler S.I. Obnaruzhenie i oproverzhenie oshibok kak sredstvo razvitija kritichnosti myshlenija // Aktual'nye psihologopedagogicheskie problemy obuchenija i vospitanija. - M.: Aspekt press, 2010. - S. 18.

5 Menchinskaja N.A. Problema uchenija i umstvennogo razvitija shkol'nikov. - M.: Pedagogika, 2009. - $218 \mathrm{~s}$.

6 Fedorov A.V. Mediaobrazovanie: istorija, teorija i metodika. - Rostov: Izd-vo CVVR, 2012. - $708 \mathrm{~s}$.

7 Sinicyn D.S. Psihologo-pedagogicheskie uslovija obuchenija informacionno-psihologicheskoj bezopasnosti podrostkov: avtoref. dis. ...kand. ped. nauk. - SPb., 2005. - $168 \mathrm{~s}$.

8 Lucenko E. L. Adaptacija testa kriticheskogo myshlenija L. Starki // VisnikHark. nac. un-tu imeni V.N. Karazina. Serija: Psihologija. - 2014. - № 11. - S. 65-70.

\section{Литература}

1 Штерн В. Монография о душевном развитии ребенка. - СПб., 1911. - 147 с.

2 Дьюи Д. Психология и педагогика мышления: перевод с англ. - М.: Лабиринт, 2009. - 189 с.

3 Зейгарник Б.В. Патопсихология. - М.: Смысл, 2007. - 367 с.

4 Векслер С.И. Обнаружение и опровержение ошибок как средство развития критичности мышления // Актуальные психолого-педагогические проблемы обучения и воспитания. - М.: Аспект пресс, 2010. - С. 18.

5 Менчинская Н.А. Проблема учения и умственного развития школьников. - М.: Педагогика, 2009. - 218 с.

6 Федоров А.В. Медиаобразование: история, теория и методика. - Ростов: Изд-во ЦВВР, 2012. - 708 с.

7 Синицын Д.С. Психолого-педагогические условия обучения информационно-психологической безопасности подростков: автореф. дис. ...канд. пед. наук. - СПб., 2005. - 168 с.

8 Луценко Е. Л. Адаптация теста критического мышления Л. Старки // ВісникХарк. нац. ун-ту імені В.Н. Каразіна. Серія: Психологія. - 2014. - № 11. - С. 65-70. 